\title{
Prisoners of suffering: perception of women on violence practiced by intimate partners
}

\author{
Prisioneiras do sofrimento: percepção de mulheres sobre a violência praticada por parceiros íntimos \\ Prisioneros de sufrimiento: la percepción de violencia de las mujeres practica por participantes intimados
}

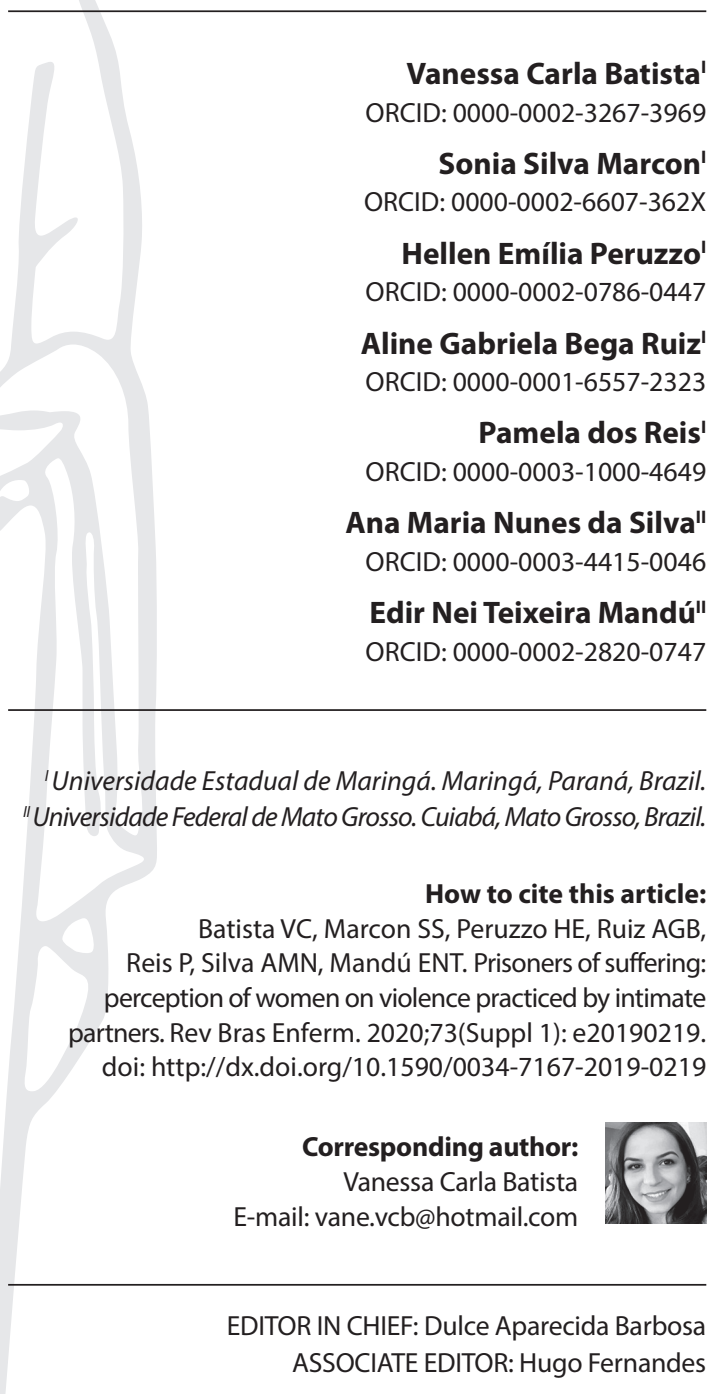

Submission: 03-15-2019

Approval: $10-12-2019$

\begin{abstract}
Objective: to describe the perceptions of women, prisoners or partners of imprisoned men who experience/experienced intimate partner violence, and how they cope with this situation. Method: a descriptive exploratory study with a qualitative approach conducted with 21 women. Empirical data collected between March and August 2018, through audio-recorded semistructured interviews, were submitted to thematic content analysis. Results: women reported experiencing different forms of violence, which triggered suffering and negative commitment in their lives, far beyond the act itself, especially by the emotional and physical marks and their consequences. They also realize that coping with violence is individual responsibility, lived in the counterpoint between the desire to overcome it and passivity. Final considerations: intimate partner violence was uniquely revealed by women as a solitary experience, with permanent consequences in the physical, emotional, patrimonial, sexual and moral spheres, and limited internal and external resources make it difficult to cope with it.

Descriptors: Violence; Women's Health; Perception; Gender-Based Violence; Comprehensive Health Care.
\end{abstract}

\section{RESUMO}

Objetivo: descrever as percepções de mulheres - presas ou parceiras de homens presos -que vivenciam/vivenciaram violência por parte do parceiro íntimo e como enfrentam essa situação. Método: estudo descritivo-exploratório, de abordagem qualitativa, realizado com 21 mulheres. Dados empíricos coletados entre março e agosto de 2018, mediante entrevista semiestruturada audiogravada, foram submetidos à análise de conteúdo temática. Resultados: as mulheres relataram vivência de diferentes formas de violência, o que desencadeou sofrimento e comprometimento negativo em suas vidas, muito além do ato em si, sobretudo pelas marcas emocionais e físicas e suas consequências. Também percebem que enfrentar a violência é responsabilidade individual, vivida no contraponto entre o desejo de superá-la e a passividade. Considerações finais: a violência de parceiro íntimo foi revelada pelas mulheres de modo singular, como vivência solitária, com consequências permanentes nos âmbitos físico, emocional, patrimonial, sexual e moral e os recursos internos e externos limitados, dificultam enfrentá-la.

Descritores: Violência; Saúde da Mulher; Percepção; Violência de Gênero; Assistência Integral à Saúde.

\section{RESUMEN}

Objetivo: describir como las percepciones de las mujeres, presas o parejas de hombres arrestados, que experimentan/experimentan la violencia de pareja y cómo enfrentan esta situación. Método: un estudio descriptivo exploratorio, con un enfoque cualitativo, realizado con 21 mujeres. Los artículos de datos del año hasta 2015, que leen audio semiestructurado, para el análisis de un ejemplo del software. Resultados: las mujeres reportan una experiencia de diferentes formas de violencia, que desencadena y reaparece en sus vidas, mucho más allá del acto en sí, en sus vidas emocionales y físicas y sus consecuencias. También se dio cuenta de que se trata de una responsabilidad individual, viva, no hay contrapunto entre el deseo de superarlo y una pasividad. Consideraciones finales: la violencia de la pareja íntima fue revelada de manera única por las mujeres como una experiencia solitaria, con consecuencias permanentes en las esferas física, emocional, patrimonial, sexual y moral, y los recursos internos y externos limitados dificultan la superación.

Descriptores: Violencia; Salud de la Mujer; Percepción; Violencia de Género; Atención Integral de Salud. 


\section{INTRODUCTION}

This paper addresses the issue of violence against women by their partners. This is part of what is called intimate partner violence (IPV) in the scientific literature. IPV can occur at different times in the life cycle of those involved and reach relationships between men, between women and between men and women. In addition, it can reach different dimensions of life - patrimonial, moral, psychological, sexual, and physical ${ }^{(1)}$.

Faced with the need to address it, the grievance has permanently challenged professionals in various fields, such as education, security, justice, health care and others. Health teams, in particular, are urged to contribute to identifying the problem, preventing related risk factors and addressing them ${ }^{(2)}$, with a view to recovering and promoting the health of victims.

Women have been greatly affected by this form of violence from their partners. Although in much of the world and in Brazil, IPV is considered a crime and a violation of human rights, this has not prevented many women from being daily victims ${ }^{(3)}$. According to theWorld Health Organization ${ }^{(4)}$, between $15 \%$ and $71 \%$ of the world's more than 1.2 billion women have been victims of intimate partner (IP) abuse at some point in their lives. In the United States, for example, it is estimated that $21 \%$ of women suffered physical and/or sexual aggression by $\mathrm{IP}^{(5)}$. In Brazil, between 2003 and 2013, the number of female fatalities from violence rose from 3,937 to 4,762 , which means an increase of $21.0 \%$ in this decade, which corresponds to 13 daily femicides ${ }^{(6)}$.

The relevance of this form of violence, in addition to its severity and quantitative growth, is evident in its traumatic consequences, which affect the multiple dimensions of victims' lives $^{(2,4)}$. Studies have shown that IPV affects women's daily life, social relationships, physical and mental health, and produces unwanted changes in their behavior, feelings, perceptions ${ }^{(3,7-8)}$ and even death.

Many societies have affirmed the relevance of this problem and invested in addressing it through different institutions, agents, policies, resources and strategies. This is based on the assumption of an emancipatory perspective that considers the diversity of the socialization processes of men and women and opposes the naturalization of gender inequalities. However, the IPV event is still strongly naturalized, seen and treated as a private matter, pertinent to intimate relationships between couples ${ }^{(9)}$. This certainly influences the way women experience it, perceive it and stand before it.

In general, there is still much to understand and do about the issue of violence from an emancipatory gender perspective. This must occur so that abused women can perceive themselves as victims of their aggressors, so that they can cope with fear and demand social resources to break the cycle of violence and to use them. There is much to be done to involve both society and women themselves in addressing the problem. The expansion of their protagonism, as one of the cycle breaking strategies, is sustained in particular by measures, strategies and social resources that can support them and change the way they see themselves in the relationship with their peers and position themselves against hierarchies built.

It is therefore relevant to broaden the understanding, from a sociocultural perspective, of how violence is experienced and perceived by women who suffer it. This without homogenizing them, as they are inserted in different contexts, have different life histories, and are victims of different aggressors.
In this direction, given the understanding of gender, it is understood that violence is not equally perceived or experienced by every woman. That is, gender relates to other elements such as age, family, social, economic and cultural conditions, without a universalizing character, but socially structured in the way these elements are associated or not in their lives ${ }^{(10)}$.

That said, IPV review research reveals that because of its magnitude and its impact on societies and the lives and health of many women, the number of scientific studies has increased ${ }^{(11)}$. However, these studies have focused mainly on those women who go to health services through a generic approach to the problem ${ }^{(11)}$. All forms of violence, including IPV against women, affect different social classes, ethnicities, races, age groups, marital status, education, regions ${ }^{(12)}$, and other specificities of their lives. Thus, the authors assume that there are many peculiarities surrounding this problem to be revealed, and that even the more vulnerable these women are, the more severely the violence will impact their lives. So far, it is considered that there is not a sufficiently broad and deep knowledge about this problem, due to its complexity and its peculiar dynamics among the various social groups/subjects.

Thus, new scientific studies on IPV should consider specificities experienced by women in their various contexts and life histories, relating them to the way they express and reinforce and/or interfere in the phenomenon, selecting people/groups and priority situations.

In this study, we seek to reveal women's experiences and perceptions about the violence suffered, having their partner as aggressor. Thus, women partners of persons deprived of liberty, or themselves deprived of liberty, were chosen. The lack of studies in this area was considered, as well as the vulnerability faced by them, especially due to the strong stigma and prejudice experienced ${ }^{(13)}$, the precariousness of their social situation, and the experience of a marital relationship permeated by fear ${ }^{(13)}$.

Theoretically, it is understood that women's reports do not reconstruct the reality of violence experienced. However, they express what matters to them, their interpretations and explanations about the issue, and how they position themselves in it. This as a product of his look directed to the lived, instructed by the sociocultural context and his life trajectory ${ }^{(14)}$.

The problem of IPV has many angles and is multicausal. However, it is closely related to the existing inequalities in social relations between men and women, built and reconstructed at the interface of the public and private spheres, due to the oppression of one gender over another ${ }^{(15)}$. There is an important socio-cultural component of gender immersed in this problem.

\section{OBJECTIVE}

To describe the perceptions of women, prisoners or partners of imprisoned men, who experience/experienced intimate partner violence, and how they cope.

\section{METHODS}

\section{Ethical aspects}

This study is part of the dissertation entitled "Violência por parceiro íntimo em mulheres de apenados". It has been approved 
by the Research Ethics Committee of the Universidade Estadual de Maringá (UEM). The participants signed the Informed Consent Form (ICF) in two copies, and to guarantee their anonymity they are identified with the letter " $D$ " (Deponent), followed by an Arabic number, indicating the order of the interviews (D1;D2...).

\section{Type of study and methodological framework}

This is a descriptive-exploratory study with a qualitative approach, theoretically based on gender understanding ${ }^{(16)}$.

\section{Data source and study setting}

The study was conducted in the city of Maringá, state of Paraná, with 21 women selected for convenience, six companions of prisoners and 15 deprived of liberty. In all cases, their partners were or have already been arrested for reasons other than violence against women. Still, according to the inclusion criteria, women should be 18 or older and have suffered or suffered IP violence. The first six were addressed in the data collection of the quantitative stage of the dissertation, which aimed to identify the prevalence and factors associated with IP violence in women prisoners, carried out with 136 women who were waiting for the visiting time in the Maringá State Penitentiary (PEM - Penitenciária Estadual de Maringá). Women who had experienced IPV and were willing to talk about it were invited. The interviews were scheduled and conducted at their homes. Those who claimed to be unable to schedule the interview after five attempts were excluded.

Given the difficulty in accessing women willing to talk about the issue, it was decided to approach others in prison situation, given the possibility of their partners have been or are in prison. Thus, 15 other women were approached in the $9^{\text {th }}$ Police Subdivision of Maringá. They were informed about the studyby invitation letter, distributed by the prison officers, containing the following information: "If you have had an IPV, if your partner is or has been arrested and you want to talk about it, let the jailer know to schedule your interview". The institution allowed the interviews to be held on three days of the week, in the afternoon. Fourteen visits to the institution were made, and interviews were conducted in a private room at the police station. Participants were included until the material obtained was deemed sufficient to deepen the object under study, as recommended in qualitative research ${ }^{(17)}$.

\section{Methodological procedures, collection and organization of data}

Data collection took place between March and August 2018, through semi-structured audio-recorded interviews, after the consent of the women, with an average duration of 30 to 60 minutes, and were conducted by the first author, guided by the question: Tell me how it was for you to have suffered IPV. When necessary, support questions were inserted: how and when did the violence begin? How did you act after an episode of violence? How did you feel about that? What is your perception of the violence suffered? What changed in your life after the event? How do you feel about it today? The semi-structured interview technique allowed exploring the issues of interest and also the free expression of women about them, with rich information. The interviews were transcribed in full, near their completion, which allowed us to add information about the nonverbal reactions of the participants when dealing with the subject.

\section{Data analysis}

Content analysis and thematic modality of the three proposed steps were performed: pre-analysis, material exploration and data processing ${ }^{(18)}$. Initially, the records were exhaustively read, aiming at familiarization with the women's reports. Then, the content of interest was selected according to the object and purpose of the research - in the form of record units. Finally, these units were organized and classified, identifying the relevant themes and categories from interpretations of explicit and implicit elements in the records, confrontations with the literature on the theme and inferences ${ }^{(17)}$. From the analysis emerged two central categories: violence as permanent suffering by the act and its consequences; and the breaking of violence manifested in the counterpoint between desire and passivity.

\section{RESULTS}

The women were between 21 and 58 years old. Most of them were white, had incomplete elementary schooling and had on average two children. Regarding marital status, 11 were cohabiting or married, and 10 were separated from their aggressor partners. The situations of violence suffered occurred regardless of whether the partners were arrested or not. Women with partners revealed that they continued to subject them to various violence because they controlled them directly or, if arrested, through family or friends. In turn, most of those arrested reported that their involvement with crime occurred through the imposition of their partner.

\section{Violence as permanent suffering: by the act and its consequences}

The women mentioned that their partners judged them, physically and verbally abused them, destroyed their things, made demands on them, subjected them to numerous controls. They also showed how their lives were and/or were compromised.

In reporting the different forms of violence experienced, women emphasized verbal and corporal aggression, food and financial deprivation, restriction of freedom to come and go, destruction of shared material goods, determination of what they could and could not do, besides imposing behaviors and practices to be adopted (by coercion and control). Faced with the damage suffered, they mentioned the physical, psychological, patrimonial and moral impairment of their lives, because the partner's violence resulted in injuries, psychological suffering, near death, material loss, autonomy, financial security and withdrawal from living with family members.

In addition to these explicitly addressed aspects, their accounts showed what made violence even more cruel to them: the permanence of violence beyond the act itself; and the fact that violence is lived as a lonely experience, although often other people were aware of the occurrences. 
Thus, for the women under study, what made the violence crueler was the fact that this fact did not occur only in reserved spaces, since it often happened in the presence of children, family and neighbors. In these situations, by becoming visible to others, the violence was manifested as aggravated.

He was really bad to me and the worst thing was that in front of his family. (D4)

That was what most struck me, hit me and my mother, the neighbors all watching [...] he throwing everything out, it was horrible. (D14)

Of the physical consequences of the violence, women reported, above all, those that remained visible to themselves and others in the form of scars or permanent marks, derived from injuries and fractures, which occurred mainly in the head and neck, even if not only. These scars made them remember the act of violence suffered.

Look how many marks I have [showing scars], I have marks everywhere, on the face, the whole body, almost killed me. All these marks I have was he who made it. (D10)

[...]. This flaw here, in the eyebrow, was he who punched and cut, you know. (D17)

This nerve in the middle [nose] I do not have, I had to do reconstruction surgery, there is no way to forget, the three times he broke my nose, there is no way to forget! (D7)

These scars were not only physical, but also psychological and evidenced the dimension and importance of the psychological suffering experienced. The invisible faces of this suffering were qualified in the difficulty of sleeping, frequent crying, depression, distrust and discredit of love, feeling of unhappiness, attempted suicide, and even refusal of pregnancy and child.

I was depressed, today I am a person who cries for anything, discredited life, no longer believe in true love, I am always suspicious of something. Before I met him I was happy, I was smiling, I was joking all the time, today I don't do that anymore, if there's violence on television I'm already crying, I'm worried, you know? It's not the same as it was before, nothing has changed for good, only for bad. (D8)

After all the violence, he sent me away and put another woman in my place [...]. I got into depression, I lost a lot of weight in my pregnancy, I didn't want the baby. When she was born, wow! I went into postpartum depression because she was his face, just like that, so I never bathed my daughter, I was angry with her because of him. (D19)

I tried to kill myself, took a lot of medicines, got sick, went to the hospital. I couldn't take it anymore, I got to a point where I couldn't, I didn't even think about the children, I was so angry at the time, I went there and took all the medicines. (D14)

Another sign of reported psychological distress, which also recalled the violence, was the continued presence of fear of the partner's violent actions, as the aggressions, as they were routine, were expected, and thus symbolically anticipated. In addition, women also reported reliving the violence suffered. The violence of their partners was not forgotten, and they had not only the emotional record of the act itself, but also the aggressor's participation, by remembering his voice and saying.

[...] because I knew that when he arrived he would beat me [...]. It was already routine, I already knew he was coming and he was going to hit me. (D7)

It's not fear, I was traumatized! When I looked at him, I could already see him hitting me, because he hit me without precision, without me doing anything. (D4)

It's been six years and I don't forget, every time I remember, it seems like today, I seem to hear his voice speaking. (D7)

Although the violence suffered often occurred under the eyes of others, it was manifest as a lonely experience, as it was accompanied by the "impossibility" of helping or supporting others, their refusal to help, even to overcome the lived experience.

He grabbed me by the hair and hit me in front of everyone on my birthday, everyone watching and who would help? He was only armed. (D7)

When he started to beat me my mother saw, when I did not want to go outside, he broke everything, the neighbors were all witnesses, they saw him assaulting me. (D11)

Why, to get rid of him, I had to do it myself, right? So I could take it. (D17)

Two other aspects that drew attention in the reports were: 1) the fact that violence exposes these women to other life and health problems; and 2) the inclusion of women in situations of illegality.

Some of the aggressors, in order to keep their partner under control and dominance, determined the behaviors they should adopt, often endangering their health by violating sexual and reproductive rights as they prevented them from leaving home, and/or seek health services, and/or forced them to use illicit chemicals.

At six months of pregnancy I had no baby clothes for my son, I did not know what it was, whether it was a girl or a boy, he would not let ... I had no prenatal. He said that I would only know when I was born, if it was a risky pregnancy, I knew nothing. (D15)

I wanted me to use drugs, forced [...] to starve, sick, locked up, I was five months pregnant, my girl weighed 60 grams! He got a lot of medicine and wanted me to take an abortion. It said: I don't want to have a child, especially if it's a girl, I want if it's a boy! (D2)

Thus, regarding the act of abortion, one deponent reported that she carried with her a feeling of guilt for the attitude taken, due to fear, pain and suffering.

I have a very big fault because when I was five months pregnant, I aborted. I was afraid of having a girl and going through everything 
I went through. See her suffer what I suffered, get her husband the same I got .... today I have a fault, it hurts me a lot, will never leave me, understand? [...]. If today l am all wrong, it was for all the violence Isuffered. (D10)

Other losses included the loss of material goods, the chance of entering the labor market, and the removal of the family. All this damage has resulted in negative feelings, and women's quality of life losses, which commonly endure:

He broke all my house, I have nothing, what I have now is because people gave me, he ended everything. (D14)

He forbade me to have contact even with my mother, with my sister, removed me from my family [...]. I started fighting with my mother over him. (D17)

He didn't want me to finish school and I just didn't finish. (D20)

The violence continued despite the arrest of the partners, because in this situation they were often forced by them to transport drugs and cell phones to the prison hidden in their private parts, which in addition to placing the woman in a situation of illegality also generated physical problems in your body.

I was a year and 11 months visiting him in jail, it didn't change, he wanted me to take drugs to him in jail and cell phone, I took, took every week. One week I didn't take it, because I was in a lot of pain, I think it was already making me sick, because I wrapped the phone in carbon paper to not beep, you know? A liquid was coming out, a very bad smell down there [intimate region]. (D7)

The beating also occurred in prison when she did not submit to her partner's requests:

[...] I went inside and told him that I had not taken [drug and cell phone], that I was in great pain, he hit me inside! Then I saw that he didn't want me, he wanted what I took. (D7)

Violence against women also had an extension outside the jail, being commanded by the prisoner and exerted by his family. The woman was often controlled by the abuser's family, who often used means to protect him in an attempt not to aggravate his criminal situation, even if this limited his care to the woman or aggravated his health situation.

[...] his mother came with a diaper [after the aggression]. "Let's go to the hospital. She said, no, no!", I said We take care here at home! She covered him, did not want anyone to know, to protect him. (D4)

His mother threw a pile of coffee powder on my head, said it was to stop the blood [after the aggression], they wouldn't let him go to the hospital because it gave him trouble. (D7)

\section{Disruption of violence: counterpoint between desire and passivity}

Some women were hoping that there would be a change in their partner's violent behavior, whether or not to do something to make it happen (interning him or leaving everything under his partner's command), finding himself in the limit and/or wishing intensely no longer suffer.

I thought like that, well, he'll get better, he'll heal, and that was going on. I arranged an internment for him, but it was only 30 days [...] returned worse, the aggressions increased! (D4)

[...] / couldn't detach myself and I hoped that he would change. (D13)

I was going to admit him; I had already told his mother that I couldn't take that life anymore. (D17)

I said, now it's going to be different, but it was even worse, because everything he wanted to do, he did and I left. Sometimes a woman doesn't want to suffer anymore, but still can't. (D19)

To withstand the violence suffered, not knowing which way to go or what decisions to take to get out of the situation, participants used some strategies, such as using sleeping pills and pain-free drugs:

There was a time that for me to take it was only on the basis of drugs, I smelled a lot. Cocaine well to say is an anesthetic. [...] I would not feel as healthy. Then I smelled a lot. (D7)

I took the medicine and was sleeping all day. Just woke up, went to the bathroom and went back to sleep. So that was life you know, just sleep, sleep, sleep. [...] / became dependent on medication, I felt bad, but I didn't have the strength to do things, take action. (D20)

They would forgive their partner successively and stay with him because of the fear of breaking the relationship. They didn't find themselves strong enough to get out of the situation, didn't know what to do or where to go:

I would forgive him, even if he cursed me, beat me, then I would forgive [...]. (D17)

I forgave because I didn't know what to do, where to go, you know? (D17)

Not all women remained in violent situations. Some revealed the overcoming of the lived, showing resilience. For them, what was important for breaking or limiting violence was changing their position, losing their fear, not forgiving their partners, imposing limits; beyond tiredness with the situation.

I think everything that happened changed my thoughts, my life, my way of thinking. I have to not want to, because I get hurt. Because if they hit once, we forgive, they will hit the second time, the third time [...]. (D17)

I lost my fear, we stop being stupid, we get tired. (D18)

Today I know that since the first slap, should have given a limit. I no longer let myself be beaten, either with words or aggression, so today I consider myself strong. (D20)

I got over it, it took a while, only I got over it. Everything has its time, but I don't want to go through what I went through again. (D19) 
Overall, women did not refer to the need for support from institutions, family members or others in a support network to address violence and did not recognize them as co-responsible in this task. Thus, the confrontation of violence is understood as the individual responsibility of the aggressed person, dependent on their own resources and the interpretation of a limit to the condition experienced by them, individually.

\section{DISCUSSION}

Women recognized IPV and were aware of both the aggression in acts and the consequences in their lives. IPV was translated by them as abuse, emotional damage, physical marks on their bodies, and as limitations on their lives and expropriation of their autonomy, lived with much suffering, being the aggressor their intimate partner regardless of whether he is or not with your restricted freedom.

The act of violence, for them, when exposed to the eyes of others, was an aggravating situation, possibly due to humiliation and public depreciation suffered with it. It was similar to what was identified in a study that analyzed female narratives about violent marital relations, in which feelings of shame, guilt or embarrassment were experienced, regardless of the manifestation of critical evaluation by others ${ }^{(19)}$. In addition, they felt permanently exposed through the "visible" and indelible marks of physical aggression registered on their bodies/face, making them remember the lived. The same was also true in the emotional and symbolic sphere through "invisible" marks ${ }^{(19)}$.

A study conducted in Salvador, state of Bahia, with women who resorted to the Special Police Station for Women Care (Delegacia Especial de Atendimento à Mulher) for violence from their partners, also found that, in the situation of violence, visible physical marks added to invisible emotional marks, and both reverberate in the subjectivity and social relations of the victims. The study also highlighted that facial marks constituted an additional resource of the male power exerted against them, for being applied in a body area of high visibility and symbolic value in our culture ${ }^{(20)}$.

Physical marks were linked to the permanence of the situation and acts of violence. In addition, the symbolic record of what happened, the fear and insecurity generated were constant in the lives of women. In particular, the feeling of the imminence of a "new" aggression created uneasiness in these women, and given the routine of aggression, and anticipating a new violent act, the suffering anticipated and continued. In this setting, the overlap of "violence" and its permanence placed women in situations bordering on vulnerability and constant suffering.

In these reports, it is evident that women were and/or found themselves alone in facing IPV. In the act itself, this was associated with the attitude taken by third parties: that of "spectators". It can be assumed that this practice is supported by the fear of also suffering possible violence (especially by recognizing the aggressor's involvement with crime and the use of weapons). However, it may also be associated with the constructed cultural idea that "breaking up a fight between husband and wife may break you up", or that "the woman who is beaten must have deserved".

In breaking the cycle of violence, facing a possible or imagined separation from their partner, the women in this study also felt lonely, not recognizing instances and resources of social support, attributing only to themselves the efforts and attitudes to leave this scenario. Thus, they specified overcoming the problem as being of an individual order.

This perspective is based, in particular, on the fact that violence against women is not widely valued as a collective and social phenomenon and to be coped with in this context, which favors their invisibility and permanence in the private sphere ${ }^{(9)}$. However, from a gender perspective, it is considered the production of this type of violence against women based on a hierarchical organization of male dominance, in historically delimited relations and culturally legitimized by inequalities between men and women built and naturalized throughout of history ${ }^{(9)}$.

As a social phenomenon, gender violence violates women's human rights, including their sexual and reproductive rights. Such violence seems to express relations of inequity between men and women, in which - by the biological advantage of their physical strength - men have benefited. Women are exposed to physical and/or psychological aggression in public and/or private spaces, with consequences in different areas of their lives, including their physical and mental health ${ }^{(9)}$.

In this regard, regarding the consequences of IPV, the women in this study highlighted those of physical and emotional priority, although in their reports it is possible to identify others, such as patrimonial ones. Physical and verbal aggression, restriction of freedom to come and go and impositions of the partner were revealed as the main forms of violence suffered and whose consequences and marks were perpetuated. Among those not clearly perceived by women, the research also identified legal or legal consequences, related to the use of illicit drugs and the action of transporting prohibited objects to the arrested partner, such as drugs and cell phones, which is a peculiar aspect of the studied population.

This peculiar aspect was mentioned by both groups of women and was present, for example, when the aggressor's family members limited care alternatives after episodes of violence at home. This is to protect the aggressor, who was already in disagreement with the courts. Thus, in addition to being unable to count on their partner's family, these women were often prevented from contacting their own family members, which also made it difficult for them to receive the care and support they needed.

The implications of violence on women's health were overwhelming, as vulnerability to various biological, emotional, patrimonial, sexual and moral problems was found, including the prevention of access to health services after the violence until prenatal follow-up. These impediments, according to the Maria da Penha Law (Lei Maria da Penha) ${ }^{(1)}$, as well as being a conduct of sexual violence, by limiting and/or nullifying sexual and reproductive rights through coercion and/or manipulation, may affect not only women's health, but also of the child, in case of a pregnancy. A study conducted in Bahia, which investigated the meanings attributed by women to the repercussions of conjugal violence, pointed to the impairment of physical and mental health and social relations, as a result of isolation and non-qualification for the labor market ${ }^{(3)}$.

Due to the wide consequences of violence, in the short and long term, such as those found in the present study, illegal abortions, the breaking of family affective bonds, the loss of material goods; 
school dropout, reduced chances of insertion in the job market, and the impediments of health care itself, looms the social need to break the cycle of violence. Due to the commitment of these different areas of women's life, there is a need to articulate the different sectors and social agents to cope with the issue of IPV.

The recognition of the violence suffered and its consequences by the women of this study, and the manifestation of the experience of a continuous suffering, lived, often on the edge, triggered in them the desire not to live this situation, to overcome it and that their daughters in the future did not experience a similar situation. However, this desire was not always fulfilled, because among them was strongly manifested the report of immobility or passivity, the inability to negotiate with the partner, a certain denial of the violence suffered, the submission and attachment to the partner, the difficulty to ask and locate help, among other aspects.

In this sense, some of them relied on the expectation of behavioral change of the partner and saw an alternative in forgiveness. Although initially proposed as a conciliatory strategy, forgiveness sometimes was anchored in a relationship of economic and emotional dependence on the partner and/or represented the denial of the situation experienced with its consequent perpetuation.

In a context of difficulty to overcome, in which often these women, feeling incapable and lonely, exposed their life and health to the limit, which seemed possible to them to "mitigate" their pain by using drugs, ingesting sleeping medications, and even attempting suicide through these substances. A mixed study conducted in the United States showed reports of suicidal ideation and suicide attempt among women victims of IPV. In addition, 34\% of women reported taking various medications for their mental and physical health regularly. A research has shown that stress, sadness, depression and unhappiness were present in the lives of most abused women ${ }^{(21)}$.

The passive position of women assumed in situations of violence often stems from fear. In this sense, research conducted with women located in NGOs and in the Reference Center for Assistance to Women in Violence in Great Florianópolis (Centro de Referência de Atendimento à Mulher em Situação de Violência da Grande Florianópolis) found that victims resort to the strategy of silence and obedience to prevent even worse aggressions ${ }^{(22)}$. Still, the fear and insecurity expressed comes from the fact that women do not know what may trigger the fury of the aggressor. Thus, fear causes the victim to omit any protective attitude, which in turn prevents the cycle of violence from being broken ${ }_{(8,22)}$ generating passivity and low self-esteem in women.

A phenomenological study conducted with women victims of conjugal violence revealed that the fact that they continue to live with the aggressor emanates from the destruction of their body self-image, which in turn reduces the ability to cope because they feel threatened, inferior and insecure ${ }^{(23)}$. Thus, the lack of support from different institutions to women and their families also contributes to the perpetuation of violence. In this regard, a study revealed that the family is one of the main bases of support. Its absence makes it difficult to break the cycle of violence, causing greater suffering for women, as it negatively interferes with their empowerment process so that they can leave the cycle of violence and start a new life ${ }^{(24)}$.

In the same vein, research conducted in the city of São Paulo revealed that fear, physical and moral aggression and retaliation by the aggressor influenced women to cancel themselves and often blocked their decision to break with violent daily life, which also led to ignorance of their rights and lack of information. However, the protection of family and/or friends was pointed as an essential factor for them to make decisions, such as denouncing the aggressor and seeking support ${ }^{(25)}$.

Likewise, a study showed that the fact that women are isolated or remain dependent on their abusive partners was related to social factors. The groups that make up the victims' contact network may be indifferent, apathetic, or insensitive to women's vulnerability. On the other hand, they have the power to strengthen ties, promoting help in their social demands and, specifically, emotional, material, services or information ${ }^{(26)}$.

Although, in the present study, most of the women were passive or unable to cope with the problem, there were those who mobilized in some way to break the situation of violence. Initiatives ranged from efforts to change one's behavior to investing in oneself. In this sense, women resiliently faced fear, changed their thinking about forgiveness toward their partners, negotiated with them, valued their own desires, and imposed limits within their love relationship.

A survey of Portuguese women found that the process of entry and exit of women in IPV relationships is long, nonlinear and consists of four phases: 1) entry - the moment when the woman falls in love and becomes imprisoned; 2) maintenance - when the woman silences, consents and remains in the relationship; 3 ) the decision to leave - the moment when she faces the problem and, finally, the 4) of (re) balance - phase in which the woman (re) finds herself with a new life ${ }^{(27)}$.

Thus, there is the need to prepare professionals to deal with the problem sensitively and effectively with those who need support, whether they seek it or not. This is also based on other studies, in which statements by women also indicate that the violence experienced by them has repercussions on their health-disease process ${ }^{(3,20)}$.

Particularly in the area of health, violence against women is commonly invisible in services, through the attribution of a private and intimate character to the phenomenon. However, in order to address this problem, from a comprehensive and resolute perspective, it is necessary the: 1) development of a work that values the health-disease process in its sociocultural interface; 2 ) mobilization of strategies for searching, identifying and valuing cases of violence against women through the registration and notification of cases; 3 ) integrated teamwork, with the provision of a network of services that articulates and communicates; 4) establishment of interpersonal relationships between professional and user, with the strengthening of bonds and the recognition of listening and orientation ${ }^{(9)}$.

Specifically, the professional nurse, as a member of the health team, can act significantly in the process of coping with violence, through welcoming strategies that place the victim as a central figure in care actions directed to the problem, in order to (re)define their destination. Conditions of secrecy and respect for their rights are maintained, as this is a situation in which women feel ashamed and stigmatized ${ }^{(28)}$. Nurses can also contribute to the development of a scientific and human practice that values, understands and considers women's experiences and perceptions, their desires and values, in relation to their life context, supported by ethical values that safeguard them. women's human rights and gender equity. 
Finally, it is essential that health services are linked to a safety net that involves different sectors of society, the judiciary, public security and social assistance. Only with integrated, continuous and networked public policies and action strategies will it be possible to reduce this important public health problem $^{(29)}$.

\section{Study limitations}

A possible limitation of the study refers to the non-deepening of the context of vulnerability and the different coping strategies experienced by women, because this study was limited to the perception of women with imprisoned partners.

\section{Contributions to nursing, health, or public policy}

Knowing the different contexts involving intimate partner violence can support the planning of actions based on an empathic and welcoming relationship, especially in the health sector. In addition, it makes professionals aware of the importance of knowing how to recognize the veiled signs of violence and to support women in facing it and breaking the cycle of violence.

\section{FINAL CONSIDERATIONS}

The women in this study were victims of various facets of the violence of their partners, which often occurred in the presence of others, exposing them and further humiliating them. In addition, the partners put their health at risk through actions aimed at restraining them or forcing them to perform certain acts detrimental not only to their well-being but to the quality of their lives. After suffering violence, women were prevented from seeking health services, if not by their partner, his family, in order to protect him from legal consequences, given his involvement with the ongoing criminality and penalty. The violence experienced generated physical, psychological, trauma and negative feelings and damage to their lives.

It is emphasized the need for attention to women involved in the context of crime, considering them more subject to stigma, rejection and the feeling of inferiority that is imposed on them daily, which generates greater social vulnerability. In addition, these women seek less health services, are more susceptible to various types of violence. And they are often treated with discrimination and indifference by society and the services that should welcome them and offer them support and care, favoring the disruption of the permanent suffering experienced.

Further studies on the subject with women living in a similar situation to this research are suggested, aiming to deepen knowledge and practices about the assistance strategies they need. And also to learn more about the experiences and problems they live, which are often veiled in health care.

\section{FUNDING}

This study was funded by the Graduate Scholarship of the Higher Education Personnel Improvement Coordination - Brazil (CAPES - Coordenação de Aperfeiçoamento de Pessoal de Nível Superior) granted to the first author.

\section{REFERENCES}

1. Ministério da Saúde (BR). Diretrizes nacionais do feminicídio, investigar, processar e julgar com perspectiva de gênero as mortes violentas de mulheres [Internet]. 2016 [cited 2018 Oct 19]. Available from: http://www.onumulheres.org.br/wp-content/uploads/2016/04/diretrizes_ feminicidio.pdf

2. Trigueiro TH, Labronici LM, Merighi MAB, Raimondo ML. The process of resilience in women who are victims of domestic violence: a qualitative approach. Cogitare Enferm. 2014;19(3):437-43. doi: 10.5380/ce.v19i3.34726

3. Carneiro JB, Gomes NP, Estrela FM, Santana JD, Mota RS, Erdmann AL. Domestic violence: repercussions for women and children. Esc Anna Nery. 2017;21(4):1-7. doi: 10.1590/2177-9465-EAN-2016-0346

4. World Health Organization. Responding to Intimate Partner Violence and Sexual Violence Against Women [Internet]. Policy Guideline: WHO; 2013; [cited 2018 nov 20]. Available from: http://apps.who.int/iris/bitstream/handle/10665/85240/9789241548595_eng.pdf;jsessionid=8C2 BDC05DFD67A0D8217C117B67B5230?sequence $=1$

5. Gonzalez FR, Benuto LT, Casas JB. Prevalence of Interpersonal Violence Among Latinas: a systematic review. Trauma Violence Abuse. 2018;114. doi: $10.1177 / 1524838018806507$

6. Waiselfisz JJ. Mapa da violência 2015: homicídio de mulheres no Brasil[Internet]. 2015 [cited 2018 Oct 13]. Brasília (DF). Available from: http://www.mapadaviolencia.org.br/pdf2015/MapaViolencia_2015_mulheres.pdf

7. Martín-Baena D, Montero-Piñar I, Escribà-Agüir V, Vives-Cases C. Violence against young women attending primary care services in Spain: prevalence and health consequences. Fam Pract. 2015;32(4):381-6. doi: 10.1093/fampra/cmv017

8. Zancan N, Wassermann V, Lima GQ. Domestic violence from the perception of battered women. Pensando Fam [Internet]. 2013 [cited 2018 Nov 23];17(1):63-76. Available from: http://pepsic.bvsalud.org/scielo.php?script=sci_arttext\&pid=S1679-494X2013000100007\&lng=pt\&nrm=iso

9. Almeida LR, Silva ATMC, Machado LS. The object, the purpose and the instruments of healthcare work processes in attending to genderbased violence in a primary care service. Interface. 2014; (18) 48:47-60. doi: 10.1590/1807-57622014.0560

10. Dantas-Berger SM, Giffin K. Violence in conjugal relations: concealing and taking sexual violence for granted. Cad. Saúde Pública. 2005;21(2):417-425. doi: http://dx.doi.org/10.1590/S0102-311X2005000200008

11. Silva LEL, Oliveira MLC. Violence against women: systematic review of the Brazilian scientific literature within the period from 2009 to 2013. Ciênc Saúde Colet. 2015;20(11):3523-3532. doi: 10.1590/1413-812320152011.11302014 
12. Presidência da República (BR). Política Nacional de Enfrentamento à Violência Contra as Mulheres. Secretaria Nacional de Enfrentamento à Violência contra as Mulheres[Internet]. 2011 [cited 2018 Nov 20]. Available from: https://www12.senado.leg.br/institucional/omv/ entenda-a-violencia/pdfs/politica-nacional-de-enfrentamento-a-violencia-contra-as-mulheres

13. Federici JF, Humbelino TM, Santos IA. Mulher de preso: expressões da violência de gênero. In: II Seminário nacional de Serviço social, Trabalho e Políticas Sociais. Universidade Federal de Santa Catarina, Florianópolis. [Internet] 2017 [cited 2018 Oct 19]. Available from: https://repositorio.ufsc.br/xmlui/bitstream/handle/123456789/180054/101_00534.pdf?sequence=1\&isAllowed=y

14. Chauí M. Convite à filosofia. Editora Ática, São Paulo; 2000.

15. Martins LCA, Silva EB, Costa MC, Colomé ICS, Fontana DGR, Jahn AC. Violence against women: reception in the family health strategy. Cienc Cuid Saude. 2016;15(3):507-514. doi: 10.4025/cienccuidsaude.v15i3.31422

16. Giffin K. Poverty, inequality, and equity in health: considerations based on a transversal gender perspective. Cad Saúde Pública. 2002;18(Suppl):103-12. doi: 10.1590/S0102-311X2002000700011

17. Nascimento LCN, Souza TV, Oliveira ICS, Moraes JRMM, Aguiar RCB, Silva LF. Theoretical saturation in qualitative research: An experience report in interview with schoolchildren. Rev Bras Enferm. 2018;71(1):228-33. doi: 10.1590/0034-7167-2016-0616

18. Bardin L. Análise de conteúdo. Lisboa: Edições 70; 2011.

19. Dourado SM, Noronha CV. The marked face: The multiple implications of female victimization in loving relationships. Physis. 2014;24(2):623643. doi: 10.1590/S0103-73312014000200016

20. Dourado SM, Noronha CV. Visible and invisible marks: Facial injuries suffered by women as the result of acts of domestic violence. Ciênc Saúde Colet. 2015; 20(9):2911-2920. doi: 10.1590/1413-81232015209.19012014

21. Karakurt G, Smith D, Whiting J. Impact of intimate partner violence on women's mental health. J Fam Violence. 2014;29(7):693-702. doi: 10.1007/s10896-014-9633-2

22. Martins VM, Bartilotti CB. "Acabou comigo como pessoa": A caracterização da violência doméstica a partir da percepção de mulheres violentadas. Cad Pesq Interdisc Cienc Hum. 2015;16(108):41-61. doi: 10.5007/1984-8951.2015v16n108p41

23. Ferraz MIR, Labronici LM. Fragmentos de corporeidades femininas vítimas de violência conjugal: uma aproximação fenomenológica. Texto Contexto Enferm. 2015;24(3):842-849. doi: 10.1590/0104-07072015003030014

24. Gomes NP, Diniz NMF, Reis LA, Erdmann AL. Rede social para o enfrentamento da violência conjugal: representações de mulheres que vivenciam o agravo. Texto Contexto Enferm. 2015;24(2):316-24. doi: 10.1590/0104-07072015002140012

25. Oliveira PP, Viegas SMF, Santos WJ, Silveira EAA, Elias SC. Women victims of domestic violence: a phenomenological approach. Texto Contexto Enferm. 2015;24(1):196-203. doi: 10.1590/0104-07072015002900013

26. Netto LA, Moura MAV, Queiroz ABA, Leite FMC, Silva GF. Isolation of women in situation of violence by intimate partner: a social network condition. Esc Anna Nery. 2017;21(1):e20170007. doi: 10.5935/1414-8145.20170007

27. Leitão MNC. Women survivors of intimate partner violence: the difficult transition to autonomy. Rev Esc Enferm USP. 2014;48(Esp):07-15. doi: 10.1590/S0080-623420140000600002

28. Barros LA, Albuquerque MCS, Gomes NP, Riscado JLS, Araújo BRO, Magalhães JRF. The (un)receptive experiences of female rape victims who seek healthcare services. Rev Esc Enferm USP. 2015;49(2):193-200. doi: 10.1590/S0080-623420150000200002

29. Moraes CL, Oliveira AG, Reichenheim ME, Gama SGN, Leal MC. Prevalence of physical intimate partner violence in the first six months after childbirth in the city of Rio de Janeiro, Brazil. Cad Saúde Pública. 2017;33(8): e00141116. doi: 10.1590/0102-311x00141116 